\title{
Non-Oil Tax Revenue on Economic Growth and Development in Nigeria
}

\author{
Festus Folajimi Adegbie, Appolos Nwabuisi Nwaobia and Olalekan Osinowo
}

\begin{abstract}
Globally, government is experiencing difficulties in generating adequate revenue to finance their activities. In Nigeria, studies have shown that the recent sharp reduction in the revenue was as a result of decline in crude oil prices which inversely affected the financial ability of government towards growth and development of the nation. To this end, this paper therefore investigated the effect of non-oil taxes on economic growth and development of Nigeria. The study employed expost facto research design. Macro data for the period 1994Q12017Q4 representing seventy-six (76) observations were obtained from CBN statistical bulletin and National Bureau of Statistics. The documents were already exposed to the scrutiny of the appropriate regulatory agencies. The data were analyzed using descriptive and inferential statistics employing multiple regressions. The study discovered that non-oil taxes (custom and excise duties, capital gain tax, company income tax, tertiary education tax and value added tax) have significant effect on economic growth. (Adj. $R^{2}=0.75, F_{(5,71)}=213.43$, $p<$ $.0 .05)$. The individual effects are also positive and statistically significant: (VAT- $\beta=8.011, t_{(76)}=2.802, \rho<0.05$, CIT- $\beta=$ $2.560, t(76)=2.383, \rho<0.05$, CED $-\beta=1.767, t_{(76)}=3.092, \rho<0.05$, CGT- $\beta=4.162, \mathrm{t}_{(76)}=3.509, \rho<0.05$, and TET $-\beta=0.161, \mathrm{t}_{(76)}=$ $2.443, \rho<0.05)$. This study concluded that non-oil taxes significantly influenced both economic growth and economic development in Nigeria. The study recommended that government must strive to sustain the current unflinching commitment towards improving non-oil tax revenue, ensure Tertiary Education Tax collected translates into real development and also ensure efficient utilization of tax payers' money to boost non-oil tax revenue collection which will then lead to economic growth and development.
\end{abstract}

Index Terms-Economic Development, Economic Growth, Gross Domestic Product, Human Development Index and NonOil Tax Revenue.

\section{INTRODUCTION}

In every country, there exists a mutual relationship between the government and the citizens such that governments provide enabling environment for businesses to thrive where citizens are productively engaged. In return for the benefit of conducive business environment put in place by the government, citizens bear the burden of the cost of infrastructure put in place by the government through tax payment. According to Lyndon and Paymaster (2016), citizens will continue to pay tax with little or no persuasion when they perceive that government will be responsible and accountable to them (citizens) through judicious use of taxpayers' money.

Across the world, there are continuous efforts by various governments to meet up with their responsibilities and fulfill

Published on May 28, 2020.

Department of Accounting, Babcock University, Nigeria.

(corresponding e-mail: lekanosinowo@yahoo.com). campaign promises. This position was alluded to in the work of James and Moses (2012) where they posited that most developed countries such as United Kingdom, United State of America, Japan and Germany who are not richly endowed with natural resources as African countries have been able to reach heights through perfectly organized tax system. Haji and Esfandiar (2016) reported that countries that are highly developed today have been able to utilize judicious tax proceeds to develop their economy, gratify the highly vulnerable and the less privileged. To this end, government prepare annual budget and have the guarantee of achieving almost $95 \%$ of the target thereby giving no room for tax evasion and non-compliance from the citizens (James \& Moses, 2012).

Nigeria in 1960s and early 1970s was well known all over the world particularly in the area of production and export of high quality agricultural produce like cocoa, ginger, rubber, groundnut, cotton among others, to most developed nations of the world. However, Ude and Agodi (2012) posited that the comparative advantage enjoyed by Nigeria over time could not be translated into economic gains due to lack of concern and investment in improving the quality Nigerian produce, thereby making the products less competitive in the international market. Many other countries blessed with oil have been able to use the proceeds from the sale of oil to develop other sectors of the economy, provide infrastructure and formulate policies to attract Foreign Direct Investment (FDI) to their respective countries. Consequently, Nigeria, unlike other oil producing nations is worst hit by the crash in world oil price.

Economic growth and development are two concepts often used interchangeably. However, contextual and practical differences exist between the two concepts. David and Anyiwe (2013) considered economic growth to be an increase in the total value of goods and services produced in a country within one year. The size of a nation's Gross Domestic Product (GDP) depends on the productivity of her economic resources. On the other hand economic development according to Grace, David and Oliver (2016), deals with policy intercession efforts by the government aimed at utilizing the growth in Gross Domestic Products (GDP) to enhance the economic and social well-being of people. This implies that economic development concern itself on improving the quality of life of people, introduction of new goods and services using modern technology, development in infrastructural facilities, improvement in both education and health services all in a bid to improve the quality of life of the citizens.

One of the fiscal measures put in place by the government of every nation to generate fund to finance the cost of governance and grow the economy is taxation. However, 
Oyewo (2013) posited that many nations often have other revenue streams like: oil, revenue from the services rendered to the public by government ministries, departments and agencies and revenue from disposal of government assets to augment tax revenue. Nigeria has realized the need to diversify her revenue base from oil to other sectors of the economy as a result of the crash in the world oil price which threw the Nigeria economy into recession (Inyiama \& Ubesie, 2016). Statistically, the CBN Statistical Bulletin 2017 revealed that price per barrel of crude oil between 2012 and 2014 hovered around $\$ 100$ and $\$ 120$ but between 2015 and 2016 price per barrel of crude oil fell to between $\$ 45$ and $\$ 32$. This led to corresponding national oil revenue including Petroleum Profit Tax (PPT) of 8.06, 6.8, 6.7, 3.7 and 2.7 trillion naira respectively for 2012 to 2016 .

Also, efforts aimed at examining the impact of non-oil tax revenue on economic growth are also in myriad of numbers. Most of the studies that examined the impact of non-oil tax revenue on economic growth linked each nontax revenue (Value Added Tax, Capital Gains Tax, Company Income Tax and excise duty) to economic growth. Therefore, the objective of this paper was to examine the impact of non-oil tax revenue (value added tax, companies income tax, customs and excise duties, capital gains tax and tertiary education tax) on the economic growth and development of Nigeria.

\section{LITERATURE REVIEW}

\section{A. Conceptual Review}

\section{1) Value Added Tax}

Izedonmi and Jonathan (2014); and Lawrence (2015) defined Value Added Tax (VAT) as a consumption tax which was introduced to replace sales tax. The primary objective of VAT introduction was to boost government revenue base as well as to make funds available for developmental purposes that with a view to accelerating economic growth (Umeora, 2013). Value Added Tax (VAT) was said to have been first invented in France by Maurice Laure who was the director of French tax authorities in 1954. The essence of VAT then was to encourage export as more VAT was levied on imported goods into France as reasonable rebate was given on export (James \& Moses, 2012). In France, VAT was used as a form of protection for French industries and also subsidy for export which made French products then to be competitive globally (Lawrence, 2015).

\section{2) Companies Income Tax}

Every Company is registered to engage business activities with a view to making profit. Also, government provide the essential services and facilities enjoyed by corporations ranging from construction of better road networks, efficient and effective telecommunication system, provision of electricity, security to water supply among others (Adegbite, 2015). It therefore follows that a symbiotic relationship exists between the government and corporate organizations where the provision of goods and services by corporate organizations requires some facilities that can majorly be taken care of by the government. Also, government needs funds to provide and sustain good business environment for business outfits to thrive. It is therefore imperative for corporate organizations to support government financially through payment of certain percentage of profit as tax to the government (Fagbemi, Uadiale \& Noah, 2010). Company Income Tax in Nigeria was introduced and regulated by Company Income Tax Act (CITA) CAP.60. Law of Federal Republic of Nigeria, 1990 and it is charged at the Rate of $30 \%$ of total profit on all companies operating in Nigeria except those companies that are specifically exempted by the Act (Adegbite, 2015). Company income tax is administered by the Federal Inland Revenue Service (FIRS) using the enabling Act (CITA) as guide.

\section{3) Customs and Excise Duty}

Customs and Excise duty is another type of non-oil tax revenue that has contributed to the economic growth of Nigeria. Customs and excise duties are forms of indirect tax which is levied on both imported and exported goods and services (Akhor, Atu \& Ekundayo, 2016). Customs duties introduces in 1860 as import duties is adjudged one of the oldest forms of modern taxation (Ekeocha, Ekeocha, Malaolu \& Oduh, 2012). Policies upon which the imposition of customs and excise duties are imposed are often tailored toward growing the economy. This can be achieved by levying more duties on some imported items that are also produced within the country to discourage its import and levying very low duties on goods and services which are required to grow the economy. In furtherance to this position, Akhor, Atu and Ekundayo (2016) also reported that customs and excise duties are good instruments for; protecting domestic companies in their infant states, regulate business activities, income redistribution and checking inflation. Increased duty on imported goods and services will definitely affect adversely the price and availability of such goods and services within the country thereby encouraging local production of such goods and services and consequently growing the economy (Ekeocha, et al., 2012). For instance, the high import duty on dairy products, textile materials, agricultural produce, beverages and the likes has helped to develop industrial investments locally with a multiplier effect on employment, output and economic growth (Komal, 2013).

\section{4) Capital Gains Tax}

In Nigeria, Capital Gains Tax is regulated by the Capital gain tax Act CAP 42 LFN 1990. Capital Gains Tax is a tax imposed when a chargeable asset is sold at a price higher than the cost of the asset (Daniel, 2014). In order to give clear description of assets on which CGT is chargeable, Joyson (2011) identified those assets liable for CGT to include; Land, Building not being used at principal place of residence or only private place of residence, machineries, Foreign currencies and stocks/Shares. According to Daniel (2014), Capital Gains (or losses) generally refer to the price of an asset when it is sold compared to its original purchase price or cost of the assets. A capital gain occurs if the value of the asset at the time of sale is higher than the initial cost or purchased price. It is on the reported gains that CGT is charged. The rate of CGT in Nigeria is $10 \%$ and it is computed on actual year basis.

\section{5) Tertiary Education Tax}

Obatola (2014) defined Tertiary Education Tax as a tax 
imposed on the adjusted/assessable profits of corporate organizations at the rate of $2 \%$ in addition to companies' income tax. Education tax was introduced in Nigeria in 1993 to generate funds for the decaying infrastructure in the Nigeria tertiary institutions by the Federal Military government through Education Tax Decree No. 7 of 1993. This decree later metamorphosed into the Education Tax Act Cap. E4, Law of Federation of Nigeria (LFN) 2004. The Education Tax Act Cap. E4 LFN, 2004 has now been repealed by the Education Tax Act 2011.

What necessitated the promulgation of this Education Tax Act was the widely recognized decline in Educational standards and the deep rot in infrastructure and other facilities at all levels of the Nigerian educational system. From the primary to secondary and tertiary levels, it was obvious that there was urgent need for emergency funding to improve educational facilities and infrastructure, restore high morale of teachers, attract and retain qualitative entrants into the profession, encourage professionalism in teaching and improve teacher education curriculum (Ugwuanyi, 2014).

\section{6) Economic Growth}

The terms economic growth and economic development are often used together and at times one mistaken for the other. However, the two terms do not mean same thing. According to Arnold (2011), Economic Growth as a term specifically means an increase and rise in the total value of goods and services produced by a country over a period usually a year. Daniel (2004) posited that economic growth is a sustained increase in per capita national output or net national product over a long period of time. It implies that the rate on increase in total output must be greater than the rate of population growth. The growth rate of a country is measured by the size of her Gross Domestic Product (GDP) (Appah, 2010). Akwe (2014) further added that it takes creative and productive nation to grow her gross domestic product (GDP) by ensuring full employment, reduced interest rate and improved output in the industrial sector. A fully engaged economy with total control of economic variables has high tendencies of improving the size of its gross domestic product GDP and thereby improving the economic growth (David \& Anyiwe, 2013).

\section{7) Economic Development}

Economic Development on the other hand is a policy intervention effort designed to achieve economic and social well-being of the people (Akwe, 2014). Economic development is therefore concerned with an improvement in the quality of life of people through the introduction of new goods and services using modern technology, infrastructural development, reduction of risk and dynamics of innovation and entrepreneurship (Arnold, 2011). The core objective of economic development is to create an enabling environment for local communities and regions to develop new ways of producing goods in such quantities that may lead to exportation to other countries as well as creating an enabling environment for businesses to thrive (Afuberoh et al., 2014)

\section{B. Theoretical Review}

\section{1) Ability to Pay Theory}

Ability to pay theory of taxation was propounded by
Adams Smith 1776. In his book titled 'the wealth of a nation' and further popularized and amplified by Author Cicil Pigou 1877 and the theory is adjudged one of the most renown and generally accepted theory of taxation is that which allows citizens to pay tax to the government in accordance to the ability of individual tax payers (Otu \& Theophilus, 2012). According to Jones and Rhoades (2011), the theory is said to have originated by the Swiss philosopher Jean Jacques Rousseau between 1712 and 1778 in the $16^{\text {th }}$ century and was scientifically extended by a number of scholars. Since the introduction of the theory, it has dominated several literatures with a view to explaining basis upon which good tax system should operate (Lawrence, 2015). This theory holds that tax should be levied progressively to the income of taxpayers where those who earn more are made to pay more tax than those on lower income. Ability to pay theory of taxation is adjudged most reasonable and fair theory of taxation owing to the fact that it takes into account the disparities in come among various tax payers (Jones \& Rhoades, 2011).Ability to pay theory has also been challenged by scholars on ground that it has no concrete approach for measuring the equity of sacrifice in absolute, proportional and marginal terms (Komal, 2013).

\section{2) The Benefit Theory of Taxation}

This theory came into existence after the ability to pay theory. Precisely, the benefit theory of taxation was developed by Thomas Hobbes (1588-1679), John Locke (1632-1704) both of whom are English philosophers and Hugo Grotius (1583-1645) a Dutch jurist in the seventeenth century (Otu \& Theophilus, 2011). The assumption of the theory is that individuals should be subjected to tax in proportion to the benefits to be received from the governments in public services and that the burden of taxes should be felt more by those people who receive the direct benefit of the government programs and social services (Akwe, 2014). Also, according to Thomas (2010), there is basically mutual relationship between the state and the taxpayers. While the taxpayers perform their civic responsibility by paying their taxes, government is the chief administrator of funds contributed by taxpayers and hence, must use tax payers' money for the benefit of the payers. The state must provide some specific social goods and services to the members of the society and who in turn contribute to the cost of these supplies in proportion to the benefits received. Those who receive more benefits from the social services financed by taxpayers should also be subjected to more tax.

\section{3) Resource Dependence Theory}

Resource dependence theory was introduced by Pfeffer and Salancik (1978) to explain how an organization's strategy, structure, and survival depend on its resources and dependency relationships with external institutions. As Pfeffer and Salancik succinctly noted, "The key to organizational survival is the ability to acquire and maintain resources". The theory stresses the impact of external forces on how organizations operate and proposes two broad tenets: (1) organizations are constrained by, and depend on, other organizations that control critical resources, and (2) to maintain autonomy, organizations attempt to manage their 
dependencies on external groups (Greening \& Gray, 1994). The degree of dependence experienced by an organization, according to a resource dependence view, is determined by the importance and concentration of its resources (Froelich, 1999). From the perspective of taxation revenue and economic growth and development, the major resources available to the government in executing its civic responsibility, that is provision of infrastructural facilities and other necessary activities for the betterment of the citizens rely solely on its ability to effectively and efficiently utilize the resource at hand (taxation revenue) irrespective of the categorization of the beneficiaries (citizens).

\section{Empirical Review}

\section{1) Value Added Tax (VAT) and Economic Growth and Economic Development}

Umeora (2013) examined the effects of Value Added Tax (VAT) on Economic Growth (GDP) in Nigeria for a period of 17 years (1994-2010). Using SPSS to analyze the time series data, the result of the simple linear regression analysis revealed that Value Added Tax (VAT) VAT has significant impact on Gross Domestic Product (GDP).

Also, Grace et al (2016) examined the effect of tax revenue on the economic growth and economic development of Nigeria using both GDP and HDI as proxies for economic growth and economic development respectively for a period of ten (10) years (2005-2014) using time series date for the period of the study. Ordinary least square (OLS) regression technique was used to analyze the data and findings from the study reveal a positive and significant relationship between tax revenue and economic growth and low impact on economic development.

In the same vein, Apere and Durojaiye (2016) investigated the relationship between Value Added Tax (VAT) and government revenue and Gross Domestic Product (GDP). The study covered from 1994 to 2014 using secondary data extracted from Central Bank statistical bulletin 2014. Phillip-Perron unit root Correlation test was also conducted to ascertain the strength of their relationship the relationship of the variables. The regression results revealed that there is a long-run significant and positive relationship between Value Added Tax (VAT) and Economic Growth proxied by Gross Domestic Products (GDP).

\section{2) Company Income Tax (CIT) and Economic Growth and Economic Development}

Margaret, Charles and Gift (2014) examined the impact of indirect tax revenues on Economic Growth (GDP) of Nigeria from 1994 to 2012 using Company Income Tax as one of the proxies for Indirect tax. The study employed secondary data generated from Central Bank of Nigeria statistical bulletin. Data analysis was carried out using descriptive statistics, correlation, T-statistics and F-Ratio. The result of the study revealed a significant positive relationship between Company Income Tax and Gross Domestic Product (GDP) of Nigeria.

Lyndon and Paymaster (2016) examined the impact of Company Income Tax and Economic Growth of Nigeria using GDP as proxy for economic growth. The study employed secondary time series data retrieved from the Statistical Bulletin of the Central Bank of Nigeria (CBN)for a period of nine (9) years (2005-2014). OLS regression analysis was carried out using SPSS version 20. The results of the analysis showed that company income tax has a significant positive impact on the economic growth of Nigeria.

Okonkwo and Chukwu (2019) conducted a study on Government Tax Revenue and economic development in Nigeria between 1996 and 2017 using Vector Autoregressive Estimates. It was showed that PPT and TTR had positive relationship with the HDI while EDT and CIT maintained negative relationship on HDI. It was concluded that tax revenue has insignificant effect on human development index in Nigeria. It was recommended that government should improve on its tax collection rate and increase its spending on education and infrastructure in order to broaden the tax base; tax revenue should be transparently and judiciously utilized for investment and in the provision of infrastructure and public goods and services so as to accelerate economic development; and government should ensure transparent and wholesome prosecution of tax offenders.

\section{3) Customs and Excise Duties (C\&ED) and Economic} Growth and Economic Development

Inyiama and Ubesie (2016) examined the effect of Customs and Excise Duties on economic growth of Nigeria. The study employed secondary data while regression analysis was used in analysing the data. The outcome of the study revealed a positive and significant relationship between Customs and Excise Duties and Gross Domestic Product or economic growth of Nigeria.

Akhor, Atu and Ekundayo (2016) examined the impact of indirect tax revenues on Economic Growth (GDP) of Nigeria from 1993 to 2013 . The study employed secondary data generated from Central Bank of Nigeria statistical bulletin. Data analysis was carried out using descriptive statistics, correlation, unit root test, co-integration test and error correction model regression. The result of the study revealed a negative and significant relationship between custom and excise duty had a negative and weakly significant impact on real gross domestic product. This implies that Customs and Excise Duties revenue for the period of the study has not contributed positively to the economic growth of the Nigeria.

4) Capital Gains Tax (CGT) and Economic Growth and Economic Development

Cornelius et al. (2016) examined the impact of tax revenue on the Nigerian economy using Capital Gains Tax as one of the proxies for tax revenue while Gross Domestic Product was used as proxy for economic growth. Time series secondary data were sourced from Central Bank Statistical Bulletin. Ordinary least square multiple regression analysis was used to establish the relationship between dependent and independent variables. The study found a positive and statistically significant relationship between Capital Gains Tax (CGT) and the economic growth (GDP) of Nigeria.

Conversely, Thomas (2010) examined the impact of Capital Gains Tax revenue on Economic Growth (GDP) of America between 1954 and 2008. The study employed time series secondary data and were analyzed using descriptive 
statistics, correlation and regression. The result of the study revealed a negative and significant relationship between Capital Gains Tax and the Gross Domestic Product (GDP) of US. The implication of this finding is that a cut in the rate of Capital Gains Tax will to increased economic growth of the United States of America.

\section{5) Tertiary Education Tax (TET) and Economic Growth} and Development

Amos, Uniamikogbo and Aigienohuwa (2017) examined tax revenue impact on economic growth of Nigeria between 1995 and 2015. The study employed time series secondary data. The result showed that Education tax has no significant effect on economic growth of Nigeria. Also, Ogbonna and Odomelam (2015) examined the impact of taxation revenue on Economic Development of Nigeria using a time series secondary data between 2000 and 2013. The data were analysed using the Econometric Model of Multiple Linear Regressions and Ordinary Least Squares (OLS) regression techniques. The result however showed that Education tax has a significant effect on economic growth of Nigeria.

\section{Methodology}

This study employed ex-post facto using time series data for the periods under study (1994-2017). This was to examine the impact of non-oil tax revenue on the economic growth and economic development of Nigeria. The population of the study was the Nigeria economy measured by the gross domestic product (GDP) and human development index (HDI) from 1994 - 2017. Sample size was not applicable in this study since the study focused on the whole Nigeria economy using macro data for 24 years from 1994 - 2017. The macro data used were: non-oil taxes which comprises of Value Added Tax (VAT), Companies Income Tax (CIT), Customs and Excise Duties (C\&ED), Capital Gains Tax (CGT) and Tertiary Education Tax (TET), Gross Domestic Product (GDP) and Human Development Index (HDI). The data used in this study was mainly secondary data obtained from Central Bank of Nigeria $(\mathrm{CBN})$ statistical bulletin, Federal Inland Revenue Service (FIRS), the Nigeria Custom Service (NCS) and United Nations Development Programme (UNDP) reports for the period of 24 years from $1994-2017$.

\section{A. Model Specification}

This study examined the effect of non-oil tax revenue on the economic growth and development of Nigeria. To carry out this study, two categories of variables were used, which are the dependent variables and the independent variables. The dependent variables are economic growth and economic development which are measured by gross domestic product (GDP) and human development index (HDP) respectively. While the independent variables are measured by non-oil tax variables which are Value Added Tax (VAT), Companies Income Tax (CIT), Customs and Excise Duties (C\&ED), Capital Gains Tax (CGT) and Tertiary Education Tax (TET).

The main functional equation of this study is

$\mathrm{Y}=\mathrm{F}(\mathrm{X})$ where

$\mathrm{Y}=$ dependent variables =economic growth GDP

$\mathrm{X}=$ independent variables $=$ non-oil tax revenue $=\mathrm{VAT}$,

CIT, C\&ED, CGT and TET

$\mathrm{Y}=\mathrm{y}_{1}$

$\mathrm{X}=\mathrm{x}_{1}, \mathrm{x}_{2}, \mathrm{x}_{3}, \mathrm{x}_{4}, \mathrm{x}_{5}$

$\mathrm{y}_{1}=\mathrm{f}\left(\mathrm{x}_{1}, \mathrm{x}_{2}, \mathrm{x}_{3}, \mathrm{x}_{4}, \mathrm{x}_{5}\right)$

$\mathrm{Y}=\mathrm{f}\left(\mathrm{x}_{1}, \mathrm{x}_{2}, \mathrm{x}_{3}, \mathrm{x}_{4}, \mathrm{x}_{5}\right)$

Therefore,

GDP = f(VAT,CIT, C\&ED, CGT, TET)---------------F1

The models:

$\mathrm{GDP}_{\mathrm{t}}=\mathrm{a}_{0}+\beta_{1} \mathrm{VAT}_{\mathrm{t}}+\beta_{2} \mathrm{CIT}_{\mathrm{t}}+\beta_{3} \mathrm{C} \& \mathrm{ED}_{\mathrm{t}}+\beta_{4} \mathrm{CGT}_{\mathrm{t}}+\beta_{5} \mathrm{TET}_{\mathrm{t}}+\mathrm{e}_{\mathrm{t}}(1)$

Where:

$\mathrm{Y}=$ economic growth and economic development

$\mathrm{X}=$ non-oil tax revenue

$\mathrm{y}_{1}=$ Economic Growth proxied by GDP

$\mathrm{X}_{1}=$ Value Added Tax (VAT)

$\mathrm{x}_{2}=$ Companies Income Tax (CIT)

$\mathrm{x}_{3}=$ Customs and Excise Duties (C\&ED)

$\mathrm{X}_{4}=$ Capital Gains Tax (CGT)

$\mathrm{x}_{5}=$ Tertiary Education Tax (TET)

Where $\mathrm{a}_{0}$ is constant of the function 1

$\beta_{1}, \beta_{2}, \beta_{3}, \beta_{4}, \beta_{5}$ are the coefficient of the proxies of independent variables;

' $\mathrm{i}$ ' represent the number of and ' $\mathrm{t}$ ' represent the number of years covered in the study.

\section{Results AND Discussions}

\section{A. Descriptive Statistics}

TABLE I: DESCRIPTIVE STATISTICS

\begin{tabular}{|c|c|c|c|c|c|c|c|}
\hline & GDP & HDI & CIT & C\&ED & CGT & TET & "VAT \\
\hline Mean & 31667.92 & 0.38 & 434.25 & 272.59 & 31.51 & 0.07 & 320.88 \\
\hline Median & 15610.88 & 0.47 & 170.20 & 205.25 & 19.27 & 0.02 & 192.70 \\
\hline Maximum & 101489.50 & 0.53 & 1755.49 & 903.00 & 80.30 & 0.28 & 803.00 \\
\hline Minimum & 964.05 & 0.00 & 12.27 & 18.30 & 0.00 & 0.00 & 7.26 \\
\hline Std. Dev. & 34713.30 & 0.18 & 506.23 & 249.89 & 30.25 & 0.08 & 296.42 \\
\hline Skewness & 0.84 & -1.51 & 1.20 & 1.42 & 0.48 & 1.07 & 0.52 \\
\hline Kurtosis & 2.15 & 3.60 & 3.39 & 4.17 & 1.63 & 2.93 & 1.64 \\
\hline Jarque-Bera & 3.41 & 4.09 & 5.64 & 4.00 & 2.68 & 4.35 & 2.79 \\
\hline Probability & 0.18 & 0.07 & 0.06 & 0.12 & 0.26 & 0.11 & 0.25 \\
\hline Observations & 23.00 & 23.00 & 23.00 & 23.00 & 23.00 & 23.00 & 23.00 \\
\hline
\end{tabular}

Source: Researcher's Computation, (2019) 


\section{1) Interpretation}

Looking at the mean and the median values of all the series in the distribution, the mean and the median are averagely of the same value, as this is one of the assumptions of normal distribution, thus the series can be said to be normally distributed. Also, the results of the standard deviation which measured the dispersion of the series from the mean revealed that all the series in the distribution sparingly dispersed from the mean. This indicated the possibility of the series exhibiting traits of normal distribution. This was confirmed from the results of the skewness, as nearly all the skewness value are within the average of the threshold (0), this is an indication that the series in the distribution are slightly skewed either positively or negatively but approximately normal in distribution, as all other variables except HDI are positively skewed. From the $\rho$-value of the Jacque-Bera test, a test for normality; since all the $\rho$-values are greater than the significant level of 5 per cent, thus the null hypothesis which states that the series are normally distributed cannot be rejected. In conclusion, the results of the standard deviation, skewness and Jacque-Bera confirmed the normality of the series in the distribution.

\section{B. Test of Hypotheses}

\section{1) Hypothesis One}

Objective One: Examine the effect of non-oil tax revenue on the Economic Growth of Nigeria.

Research Question: What is the effect of non-oil tax revenue on the economic growth of Nigeria?

Research Hypothesis: Non-oil tax revenue has no significant effect on the Economic Growth of Nigeria

Model One: $\mathrm{LGDP}=\mathrm{a}_{0}+\beta_{1} \mathrm{LVAT}+\beta_{2} \mathrm{LCIT}+\beta_{3} \mathrm{LCED}+$ $\beta_{4} \mathrm{LCGT}+\beta_{5} \mathrm{LTET}+\mathrm{e}$

Prior to the main estimation, the most appropriate lag length for the model was first determined using VAR Lag Order Selection Criteria. The result of the test is shown in Table II.

TABLE II: RESULT OF THE OPTIMAL LAG LENGTH SELECTION CRITERIA

\begin{tabular}{|c|c|c|c|c|c|c|}
\hline Lag & LogL & LR & FPE & AIC & SC & HQ \\
\hline 0.000 & 519.4596 & NA & $1.11 \mathrm{e}-14$ & -15.102 & -14.906 & -15.024 \\
\hline 1.000 & $1263.110 *$ & $1334.197 *$ & $1.02 \mathrm{e}-23 *$ & $-35.915^{*}$ & $-34.54413 *$ & -35.372 \\
\hline 2.000 & 1334.262 & 115.0982 & $3.72 \mathrm{e}-24$ & -36.949 & -34.403 & -35.940 \\
\hline 3.000 & 1355.732 & 30.94232 & $6.08 \mathrm{e}-24$ & -36.522 & -32.801 & $-35.047^{*}$ \\
\hline 4.000 & 1390.049 & 43.40129 & $7.24 \mathrm{e}-24$ & -36.472 & -31.576 & -34.532 \\
\hline 5.000 & 1558.147 & 182.9302 & $1.85 \mathrm{e}-25$ & -40.357 & -34.286 & -37.952 \\
\hline 6.000 & 1624.559 & 60.55197 & $1.08 \mathrm{e}-25$ & -41.252 & -34.006 & -38.381 \\
\hline 7.000 & 1665.731 & 30.27365 & $1.63 \mathrm{e}-25$ & -41.404 & -32.983 & -38.067 \\
\hline 8.000 & 1780.107 & 63.91578 & $4.02 \mathrm{e}-26$ & -43.709 & -34.113 & -39.906 \\
\hline
\end{tabular}

* indicates lag order selected by the criterion

Source: Researcher's Computation, (2019)

Where:

LR: Sequential Modified LR test statistic (each test at 5\% level)

FPE: Final Prediction Error

AIC: Akaike Information Criterion

SC: Schwarz Information Criterion

HQ: Hannan-Quinn Information Criterion

The results of the optimal lag length selection using Sequential Modified LR test (LR), Final Prediction Error (FPE), Akaike information criterion (AIC) and Schwarz information criterion (SC) revealed that the appropriate lag length for this model is 1, except Hannan-Quinn information criterion (HQ). In real terms, it implies that it would take one (1) before the impact of the independent variables could be felt on the dependent variable, although this is only applicable when estimating the short-run model as every shocks in the short run would have converged in the long run.

After determining the most appropriate lag length, the ARDL bound test was carried out to ascertain the existence of long-run relationship between the independent variables (LCIT, LCED, LCGT, LTET, LVAT) and the dependent variable GDP. The result of the ARDL model is presented in Table III.
TABLE III: FULL INFORMATION ON THE EFFECTS OF NON-OIL TAX REVENUE ON ECONOMIC GROWTH

\begin{tabular}{|c|c|c|c|c|}
\hline \multicolumn{5}{|c|}{ Panel A: Long-Run Estimates } \\
\hline \multicolumn{5}{|c|}{ Dependent Variable: LGDP } \\
\hline Variable & Coefficient & S.E & t-stat & Prob \\
\hline LCED & 1.767 & 0.572 & 3.092 & 0.000 \\
\hline LCGT & 4.162 & 1.186 & 3.509 & 0.000 \\
\hline LCIT & 2.560 & 1.074 & 2.383 & 0.022 \\
\hline LTET & 0.161 & 0.066 & 2.443 & 0.018 \\
\hline LVAT & 8.011 & 2.859 & 2.802 & 0.003 \\
\hline $\mathrm{C}$ & 26.440 & 11.839 & 2.233 & 0.024 \\
\hline \multicolumn{5}{|c|}{ Panel B: Short -Run Estimates } \\
\hline Variable & Coefficient & S.E & t-stat & Prob \\
\hline $\mathrm{D}(\mathrm{LCED})$ & -0.090 & 0.026 & -3.445 & 0.001 \\
\hline $\mathrm{D}(\mathrm{LCGT})$ & 0.073 & 0.072 & 1.007 & 0.318 \\
\hline $\mathrm{D}(\mathrm{LCIT})$ & -0.048 & 0.032 & -1.489 & 0.142 \\
\hline $\mathrm{D}(\mathrm{LTET})$ & -0.036 & 0.011 & -3.335 & 0.001 \\
\hline $\mathrm{D}(\mathrm{LVAT})$ & -0.306 & 0.087 & -3.504 & 0.001 \\
\hline $\operatorname{ECM}(-1)$ & -0.024 & 0.001 & -19.560 & 0.000 \\
\hline \multicolumn{2}{|c|}{ Panel C: Diagnostic Tests } & Statistic & Prob. & \\
\hline \multicolumn{2}{|l|}{ Bound Test } & 49.901 & 0.000 & \\
\hline \multicolumn{2}{|c|}{ Serial Correlation } & 0.889 & 0.426 & \\
\hline \multicolumn{2}{|c|}{ Heteroscedasticity } & 0.827 & 0.613 & \\
\hline \multicolumn{2}{|l|}{ Linearity Test } & 0.772 & 0.149 & \\
\hline \multicolumn{2}{|c|}{ Adjusted R-square } & 0.754 & & \\
\hline \multirow{2}{*}{\multicolumn{2}{|c|}{ F-stat }} & 213.432 & 0.000 & \\
\hline & & CUSUM & CUSUMSQ & \\
\hline \multicolumn{2}{|l|}{ Stability Test } & Stable & Stable & \\
\hline
\end{tabular}

Notes: Table II reports the long-run estimates, short run estimates and the diagnostic tests for the relationship between non-oil tax revenue and economic growth. The dependent variable is the logarithm of gross domestic product and the independent variables are the logarithms of custom and excise duties, capital gain tax, company income tax, Tertiary

Education Tax and value added tax 

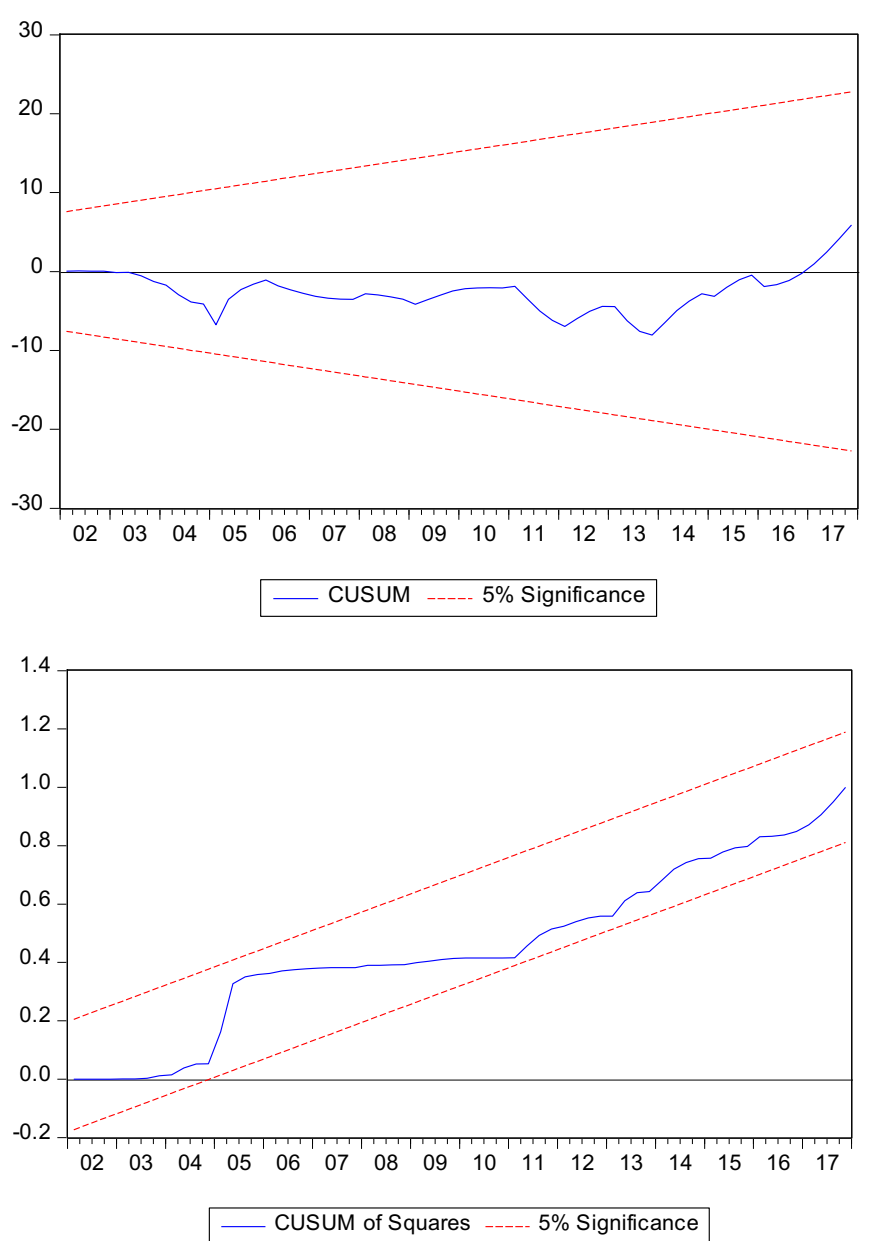

\section{Interpretation}

The value of F-Stat is 49.901 and it is greater than the critical values bound at upper bound (I1) of 4.26, 3.5 and 3.13 at 1 percent. This implies that the variables co-moved in the long run. Having found a long-run relationship between economic growth and custom and excise duties, capital gain tax, company income tax, Tertiary Education Tax and value added tax, the study then estimate the longrun and the short-run elasticities. The empirical results for the model, obtained through normalizing economic growth and non-oil tax revenue in the short and long run are reported in Table III.

\section{The Long-Run Dynamics}

The estimated long-run coefficients (elasticities) for the UECM model are given in the tables Panel A of Table III. In the long run, the results show that custom and excise duties, capital gain tax, company income tax, Tertiary Education Tax and value added tax have positive relationship economic growth. This implies that increases in custom and excise duties, capital gain tax, company income tax, Tertiary Education Tax and value added tax will lead to increase in the economic growth in Nigeria. Furthermore, there is evidence of a long-run significant relationship that custom and excise duties, capital gain tax, company income tax, Tertiary Education Tax and value added tax with economic growth in Nigeria $($ LCED $=1.767, \mathrm{t}$-test $=3.092$, $\rho=0.000<0.05$, LCGT $=4.162$, t-test $=3.509, \rho=0.000<0.05$, LCIT $=2.560$, t-test $=2.383, \rho=0.022<0.05$, LTET $=0.161$, $\mathrm{t}$-test $=2.443, \rho=0.018<0.05, \quad$ and $\mathrm{LVAT}=8.011$, $\mathrm{t}$-test $=$ 2.802, $\rho=0.003<0.05$ ). This implies that custom and excise duties, capital gain tax, company income tax, Tertiary Education Tax and value added tax are significant factors influencing changes in economic growth in Nigeria. Also, a 1 per cent increase in custom and excise duties, capital gain tax, company income tax, Tertiary Education Tax and value added tax will lead to $1.767,4.162,2.560,0.161$ and 8.011 per cent increase in economic growth in Nigeria respectively in the long run. Thus, the null hypothesis that there is no significant effect of non-oil tax revenue has no significant effect on the economic growth in Nigeria was rejected and accept the alternative hypothesis that there is significant relationship that between non-oil tax revenue on economic growth in Nigeria.

\section{E. Short-run Dynamics}

The purpose of this section is for two reasons. First, is to examine if changes and the statistical significance experienced in the long run also exist in the short run model. Second, is to examine the degree of adjustment back to equilibrium using the error correction term. The short-run adjustment process is measured by the error correction term $\mathrm{ECM}_{\mathrm{t}-1}$ and it shows how quickly variables adjust to a shock and return to equilibrium. For stability, the coefficient of $E \mathrm{CM}_{\mathrm{t}-1}$ should carry the negative sign and be statistically significant.

The result shows that in the short-term only capital gain tax has a positive insignificant relationship with economic growth $\{\mathrm{D}(\mathrm{LCGT})=0.073, \quad \mathrm{t}$-test $=1.007, \quad \rho>0.05$. Conversely, there is evidence that custom and excise duties, Tertiary Education Tax and value added tax have negative and significant relationship with the economic growth, $\{\mathrm{D}(\mathrm{LCED})=-0.090, \mathrm{t}$-test $=-3.445, \rho<0.05, \mathrm{D}($ LTET $)=-$ 0.036 , t-test $=-3.335, \rho<0.05$ and $\mathrm{D}($ LVAT $)=-0.306$, t-test $=$ $-3.504, \rho<0.05)$. In addition, the estimated coefficient for the $\mathrm{ECM}_{\mathrm{t}-1}$ reported in Panel $\mathrm{B}$ of 4.3 is negative and statistically significant $(\mathrm{ECM}=-0.024$, t-test $=-19.560$, $\mathrm{p}<0.05$ ). This implies that deviations from economic growth equilibrium path are corrected by nearly 2.4 per cent over the following quarter. The statistical significance of the $\mathrm{ECM}_{\mathrm{t}-1}$ confirms the presence of long-run equilibrium relationship between economic growth and non-oil tax revenue in Nigeria.

The Adjusted R-square is 0.75 , this implies that custom and excise duties, capital gain tax, company income tax, Tertiary Education Tax and value added tax explains about 75 per cent changes in economic growth, while the remaining 25 per cent were other factors affecting changes in economic growth but were not captured in the model. In addition, the F-statistic of 213.43 is statistically significant at 5 per cent level of significance; this implies that custom and excise duties, capital gain tax, company income tax, Tertiary Education Tax and value added tax jointly explains changes in economic growth in Nigeria.

\section{F. Diagnostic Test}

\section{1) The Linearity Test}

The linearity assumption of ARDL test was estimated using:

\section{2) Ramsey Reset Test}

F-statistics of 0.772 and its $\rho$-value is of 15 per cent is greater than 5 per cent chosen level of significance, thus the 
null hypothesis of linearity cannot be rejected. This implies that the model is correctly specified and that there is a linear relationship between the economic growth and custom and excise duties, capital gain tax, company income tax, Tertiary Education Tax and value added tax in Nigeria.

\section{3) The Heteroskedasticity Test}

Breusch-Pagan Test for Heteroskedasticity was conducted to test is the covariance of the estimated model error term is constant or not. The result suggests that a statistic of 0.827 is not statistically significant at 5 per cent level of significance, this implies that the null hypothesis of homoscedasticity could not be rejected; thus there is evidence that the covariance of the error terms have a constant finite variance.

\section{4) The Breusch-Godfrey Serial Correlation LM Test}

The Breusch-Godfrey Serial Correlation LM Test was carried out to determine if successive error terms are correlated. The probability value of F-statistic of 0.889 is in favour of the null hypothesis that there is no serial correlation in the residuals up to the specified lag order at 5 percent significant level. Thus, the study concluded that the successive error terms were not correlated in the estimated model for custom and excise duties, capital gain tax, company income tax, Tertiary Education Tax and value added tax and economic growth.

\section{5) Stability Test (CUSUM and CUSUMSQ Residual Test)}

The CUSUM and CUSUMSQ test for stability is meant to determine the appropriateness and the stability of the model. In addition, the CUSUM and CUSUMSQ tests are used to show whether the model is stable and is suitable for making long run decision. The CUSUM and CUSUMSQ are also reported in Panel C. For the Nigeria, the CUSUM test also shows that the estimated model is stable; this is because the plot of CUSUM statistic stays within a 5\% significance level portrayed by two straight lines.

\section{DISCUSSION OF FINDINGS}

\section{A. Influence of non-oil taxes on Gross Domestic Product (GDP)}

The result of the regression analysis reveals that VAT exerts significant positive effect on GDP. This finding is in agreement with submissions of Umeora (2013), Onaolapo et al (2013), Lyndon and Paymaster (2017) who all found a significant positive relationship between VAT and economic growth. Conversely, Grace et al (2016), Lawrence (2015) and Akhor et al (2016) as their studies also found an insignificant negative relationship between VAT and Economic growth. Considering the magnitude of the value of VAT compared to other non-oil taxes, it reflects that its impact will be felt when relating to economic growth. This study does reject the null hypothesis which states that value added tax have no significant effect on economic growth in Nigeria. Therefore, it is concluded that value added tax has significant effect on GDP, which implies that the alternate hypothesis is accepted while the null hypothesis is rejected.

The relationship between Companies Income Tax (CIT) and Economic Growth (GDP) is also shown in Table II. From the result, Companies Income Tax (CIT) has significant positive relationship with Economic Growth proxy (GDP) at 5\% chosen level of significance. This suggests that Companies Income Tax contributes significantly to the growth of Nigeria's GDP within the period under review. This finding is line with previous studies of Margaret et al (2014), Adegbite (2015), Onakoya and Afintinni (2015) and Lyndon and Paymaster (2016). There is however no study available that has contrary findings to this study. This study thus rejects the null hypothesis which states that companies' income tax has no significant effect on economic growth in Nigeria. Therefore, it is concluded that companies' income tax has significant effect on GDP, which implies that the alternate hypothesis is accepted while the null hypothesis is rejected.

This study also found a positive relationship between Customs and Excise Duties and Economic growth for the period under review. The relationship between Customs and Excise Duties and Economic Growth and Economic Development is not statistically significant at $10 \%$ level of significance. This implies that Customs and Excise Duties have not contributed significantly to the Nation's Gross Domestic Products (GDP). This finding is in alignment with the findings of Inyama and Ubasie (2015). Therefore, this study does reject the null hypothesis which states that custom and excise duties have no significant effect on economic growth in Nigeria. Therefore, it is concluded that custom and excise duties has significant effect on GDP, which implies that the alternate hypothesis is accepted while the null hypothesis is rejected.

\section{CONCLUSION AND RECOMMENDATION}

Based on the findings of this study, the following conclusions were drawn:

The quantum of Non-oil tax revenue collected every year is on the increase particularly in the last couple of years. The vigor to generate revenue to the nation's coffers for the period of this study is more with the Federal Inland Revenue Service than the Nigeria Customs Service. This is evident in the contribution of Value Added Tax, Companies Income tax and Tertiary Education Tax collected by the FIRS to the growth of Nigeria economy. Custom and excise duties, Capital gain tax, Value Added Tax, Companies Income Tax and Tertiary Education Tax contribute significantly to the economic growth of Nigeria. This is anticipated to be resultant effects of revenue generating policies such as tax amnesty, tax Identification Number (TIN), Voluntary Assets and Income Declaration Scheme (VAIDs) among others. The significant contribution of customs and excise duties is ascribed to the strengthening of the Nigeria borders by men of the Nigeria customs, and increases in the level remittances of generated revenue to government coffers. Therefore, oil tax revenue can stimulate the economy growth and development of Nigeria.

The following recommendations become imperative based on research findings as well the conclusions drawn from the findings. It is hoped that proper implementation and application of these recommendations will go a long way in improving the economic growth and development of Nigeria.

i. Federal Inland Revenue Service should strive to sustain the current unflinching commitment towards 
improved revenue as evident in VAT, CIT and ED collection. This can be achieved by fine-tuning the current policies (VAIDs, TIN, Tax Amnesty) in the light of unfolding business environment so as to capture more taxpayers into the tax net and to harness new tax areas. Also, tax official should be trained from time to time to enable them take on company tax adviser on issues that involve high degree of technicalities.

ii. With respect to customs and excise duties, Nigeria Customs Service must be pushed by government to live up to expectation by improving on it revenue generating drive. This can be achieved by maintaining surveillance along Nigeria borders, improved patrol system by men of proven records of integrity commitment. Stringent penalties should mete to officers who use their positions for selffinancial aggrandizement at the detriment of the Nation. This will dissuade officers from engaging unscrupulous and sharp practices. Also, a platform for e-auctioning of items as well that which facilitates speedy remittances of revenue to the single treasury account should be created.

iii. Tertiary Education Tax must improve Education Tax utilization so as to ensure that Tertiary Education Tax collected by FIRS translates into real development. To achieve this, funds disbursed to beneficiary institution must be properly monitored so as to achieve the purpose for which the fund was disbursed. Drivers of beneficiary institutions must ensure judicious utilization of the funds giving to them as well held accountable for their actions. However, defaulter should be made to face the weight of the law regardless of whose interest is at stake.

\section{CONTRIBUtion to KNOWLEDGE}

The study provides tax authorities and policy makers the important input needed to formulate policies that will enhance increase in economic growth and development of non-oil tax revenue in Nigeria This study is significant to research as it contributes to the effect of non-oil tax revenue on the economic growth and economic development of Nigeria. Theoretically, the study lent credence to ability to pay and resource dependency theory respectively from the fact that tax must be capable of being collected and paid with ease in such a manner that the burden will not be too much on the tax payer.

\section{REFERENCES}

Adegbite, T. (2015). Analysis of the effects of corporate income tax (CIT) on revenue profile in Nigeria. American Journal of Economics, Finance and Management, 24(2), 312-319.

Afuberoh, K., \& Okoye, E. (2014). The impact of taxation on revenue generation in Nigeria. International Journal of Public Administration and Management Research, 2(2), 2247.

Akhor, S., Atu, E., \& Ekundayo, O. (2016). Impact of indirect tax revenue on economic growth: The Nigeria experience. Igbinidion University Journal of Accounting, 2(2), 62-87.
Akwe, J. (2014). Impact of non-oil tax revenue on economic growth: The Nigerian perspective. International Journal of Finance and Accounting. 3(5), 300-309.

Amos, O., Uniamikogbo, E. \& Aigienohuwa O. (2017). Tax revenue and economic growth of Nigeria. Scholars journal of Economics, Business and Management, 4(10), 696-702

Apere, T., \& Durojaiye, O. (2016). Impact of Value Added Tax on government evenue and economic growth in Nigeria. International Journal of Management and Applied Sciences, 2(7), 92-97.

Appah, E. (2010). The problem of tax planning and administration in Nigeria: The federal and state government experience. International Journal of Labour and Organizational Psychology, $6(10), 1-14$

Arnold, M. (2011). Tax policy for economic recovery and growth. The Economic Journal. 12(1) 59-80.

Cornelius, M., Ogar, A., \& Oka, F. (2016). The impact of tax revenue on economic growth: $\quad$ Evidence from Nigeria. IOSR Journal of Economics and Finance, 7(1), 32-38.

Daniel, J. M. (2014). The overwhelming case against Capital Gains Tax. International Trade policy.

David, U., \& Anyiwe, M. A. (2013). Tax structure and economic growth in Nigeria: Disagregated empirical evidence. Research Journal of Finance and Accounting, 4(2), 65-80.

Ekeocha, P., Ekeocha, C., Malaolu, V \& Oduh, M. (2012). Revenue implication of Nigeria's tax system. Journal of Economic and Sustainable Development, 3(8), 2222-2855.

Fagbemi, T, Uadiale, O. \& Noah, A. O. (2010). The ethics of tax evasion: Perceptual evidence from Nigeria. European Journal of Social Sciences, 17(3), 360-371.

Froelich, K. A. (1999). Diversification of Revenue Strategies: Evolving Resource Dependence in Non-profit Organizations. Non-profit and Voluntary Sector Quarterly, 28(3), 246-268.

Grace, N., David, O., \& Oliver, O. (2016). Empirical analysis of effects of tax revenue on economic development of Nigeria. Asian International Journal of Social Science, 6(10), 604-613.

Greening, D. W., \& Gray, B. (1994). Testing a Model of Organizational Response to Social and Political Issues. Academy of Management Journal, 37(3), 467-498.

Haji, A. N., \& Esfandiar, D. (2016). The impact of the implementation of Value Added Tax on economic growth and the budget deficit. Journal of International Business Management, 10(30), 6740-6744.

Inyiama, O., \& Ubesie, M. (2016). Effects of Value Added Tax and Customs and Ecxise duties on Nigeria economic growth. International Journal of Managerial Studies and Research, 4(10), 5362.

Izedonmi, F., \& Jonathan, A. (2014). The role of Value Added Tax in the economic growth of Nigeria. British Journal of Economics Management and Trade, 4(12),1999-2007.

James, A., \& Moses, A. (2012). Impact of tax administration on government revenue in developing economy- A Case of Nigeria. International Journal of Business and Social Science, 3(8), 99-113.

Jones, S., \& Rhoades, C. (2011). Principles of Taxation for Business and Investment Planning, 14th Edition. Amazon, Tryprime.

Joyson, M. (2011). The economic impact of corporate tax rate reduction on Canadian manufacturers and exporters. www.cme-mee.ca. Retrieved on 03.09.2018.

Komal, O. (2013). An analysis of the impact of Value Added Tax in Delhi. Global Journal of Management and Business Studies, 3(8), 277-286.

Lawrence, K. (2015). The effect of Value Added Tax on economic growth in Kenya. International Academic Journal of Economics and Finance, 1(15), 10-30.

Lyndon, M., \& Paymaster, B. (2016). The impact of Company Income Tax and Value Added Tax on economic growth: Evidence from Nigeria. European Journal of Accounting, Auditing and Finance research, 4(7), 106-112.

Margaret, N., Charles, O., \& Gift, N. (2014). Taxation and economic growth in Nigeria: A granger causality approach. International Journal of Research in Management Sciences and Technology, 2(3), 64-80.

Obatola, S. O.. (2014). The Rudiments of Nigeria Taxation ( $1^{\text {st }}$ Edition) Lagos, Nigeria. ASCO Publishers.

Ogbonna, G. \& Odoemelam, N (2015). Impact of taxation economic development of Nigeria: 2000 - 2013. Journal of Social and Policy Research Development, 9(1), 251-267.

Okonkwo, I. V., \& Chukwu, K. O. (2019). Government Tax Revenue and economic development in Nigeria: 1996-2017. International Journal of Research in Business, Economics and Management, 3(3), 91-105. 
Onaolapo, A., Aworem, R., \& Ajala, O. (2013). Assessment of Value Added Tax and its effects on revenue generation in Nigeria. International Journal of Business and Social Science, 4(9), 220-225.

Onakoya, S., \& Afintini, D. (2016). Taxation and economic growth in Nigeria. Asian Journal of Economic Modeling, 4(4). 199-210.

Otu, H., \& Theophilus, O. (2012). The effect of tax revenue on economic growth in Nigeria (1970- 2011). International Journal of Humanities and Scocial Science Invention. ISSN (online): 2319-7722.

Oyewo, B. (2013). Taxation and tax policy as government strategy tool for economic development in Nigeria. IOSR Journal of Business and Management, 13(5), 33-40.

Pfeffer, J., and Salancik, G. R. (1978). The External Control of Organizations: A Resource Dependence Perspective. New York: Harper Collins.

Thomas, L. H. (2010). Economic effect of Capita Gains Taxation (CGT). Congressional Research Service.

Ude, D., \& Agodi, J. (2012). Investigation of the impact of non-oil revenue on economic growth of Nigeria. International Journal Science and Reaserch, 3(11), ISNN (online):2319-7065, 2571-2577.

Umeora, C. (2013). The impact of Value Added Tax (VAT) on the economic growth of Nigeria. Journal of Economic and Sustainable Development, 4(6), 190-201. 